Review

\title{
Perspectives on the Use of Germinated Legumes in the Bread Making Process, A Review
}

\author{
Denisa Atudorei * and Georgiana Gabriela Codină *(i) \\ Faculty of Food Engineering, Stefan cel Mare University of Suceava, 720229 Suceava, Romania \\ * Correspondence: denisa.atudorei@fia.usv.ro (D.A.); codina@fia.usv.ro (G.G.C.); Tel.: +40-758-600-035 (D.A.); \\ $+40-745-460-727$ (G.G.C.)
}

Received: 17 August 2020; Accepted: 6 September 2020; Published: 8 September 2020

\begin{abstract}
Nowadays, it may be noticed that there is an increased interest in using germinated seeds in the daily diet. This high interest is due to the fact that in a germinated form, the seeds are highly improved from a nutritional point of view with multiple benefits for the human body. The purpose of this review was to update the studies made on the possibilities of using different types of germinated legume seeds (such as lentil, chickpea, soybean, lupin, bean) in order to obtain bakery products of good quality. This review highlights the aspects related to the germination process of the seeds, the benefits of the germination process on the seeds from a nutritional point of view, and the effects of the addition of flour from germinated seeds on the rheological properties of the wheat flour dough, but also on the physico-chemical and sensory characteristics of the bakery products obtained. All these changes on the bread making process and bread quality depend on the level and type of legume seed subjected to the germination process which are incorporated in wheat flour.
\end{abstract}

Keywords: germination process; legumes; technological process; bread quality

\section{Introduction}

Seed germination is defined as the process of developing a new plant. From a mechanical point of view, the germination process can be described as an interaction between the protective coating of the seeds and the force of pushing on it by the developing seed embryo [1,2]. Germination includes three stages. The first one consists of the absorption of water by the dried seeds and the onset of the mRNA biosynthesis of the seed. The second stage is characterized by the coleoptile elongation of the seed. This is the most important phase because here all the metabolic and physiological processes of the seed are reactivated. The success of this stage is influenced by the external germination conditions, but also by the seed phytohormones. The third stage consists of the continuous absorption of water and the emergence of the radicle due to the development of the seed embryo axis [3].

Lately, interest in the consumption of germinated cereals has grown a lot due to several reasons. Mainly, it is related to the improving of the human health, correlated to the fact that the germination process is a relatively simple one because it does not require special working techniques. The germination process presents a number of advantages related to the fact that it improves the nutritional composition of the seeds and its content in bioactive substances. Different studies have shown that the germination process, if performed correctly, may increase the nutrients' availability (amino acids, minerals, vitamins, etc.) [4-7] and at the same time decrease the antinutrient compounds from the seeds [8-11]. The international literature has highlighted that the germination process increases the amount of phenolic compounds which are chemical compounds that have antioxidant action. At the same time, the germination process activates the hydrolytic enzymes from seeds, which favors the digestion process of some compounds such as starch and proteins [12]. Some researchers have highlighted that germination leads to the activation of endo-enzymes in seeds, such as proteases and 
amylases, which help break down macromolecular substances such as proteins and carbohydrates and facilitate the digestibility of nutritional compounds from seeds. At the same time, the germination process contributes to the decrease in the antinutritional factors content and to the activation of some enzymes which exist in the seeds. Thus, germination is a process that allows improving the nutritional composition of seeds [4]. Some studies emphasize that the germination process increases the content of flavonoids [13-17]. Studies in the field also indicates that the germination process leads to the decrease in some antinutritional factors, which favors a higher bioavailability of the nutritional compounds from the seeds subjected to the germination process [18-20].

Due to the health benefits of germinated seeds, different studies have reported on the incorporation of germination seeds into various food manufacturing recipes, such as: biscuits [21,22], beverages [23], baby purees [24], muffins [25,26], and yogurt $[27,28]$. Given the fact that bread is one of the main foods from the daily diet of the population, attempts have been made to improve its quality with flour obtained from germinated legumes. The addition of the germinated legumes in bread recipe led to changes in the dough rheological properties, but also on the physico-chemical and sensory properties of the bread samples obtained. The purpose of this review was to highlight the current state of studies in the field related to the possibility of using germinated seeds in the bread making recipe, underlining the changes brought by germinated seed addition on the technological process and the bread quality characteristics.

\section{Description of the Germination Process}

Germination is the first and foremost important process for the plants' cultivation and the production of vegetables and cereals. Germination is a process influenced by many genetic, endogenous, but also environmental factors, and consists of a series of cellular processes which produce various changes in the structure of the cell, some being visible to the naked eye. The germination process is being studied even today to fully elucidate its mechanism [29]. Some researchers have reported that the germination process, used for plant reproduction, is influenced not only by abiotic factors, but also by biotic stressors, such as pathogens and infestants [30]. Other studies have shown that the influence of environmental factors, such as temperature, oxygen content, soil moisture and salinity has an important impact on the germination process [31].

The germination process used for plant reproduction is a complex process which consists of several stages. The first stage corresponds to the absorption of water by seeds. Water absorption depends on seed composition and the permeability of the outer shell. The absorption of water exerts a pressure on the outer layer of seed protection leading to its deterioration in order to develop the root. Along with these physical changes in the structure of the seed, a series of metabolic changes also take place. Thus, the substances stored in the endosperm are solubilized to give rise to new tissues. Thus, starch is broken into simpler forms, namely simple sugars (glucose and maltose), and the proteins, to amino acids and amides. At the same time, the enzymes are activated, presenting an important role in the germination process. In addition, hormones also play important roles in the germination process, which help nutrients transport and the formation of new compounds that are needed for the seed development. Studies have shown that in the case of some seeds, after $12 \mathrm{~h}$ from the beginning of the germination process, the process of cell division begins in order to start the development of the component parts of the future plant. The germination process is influenced by a number of factors, such as: seed integrity, water used for germination, parameters of air from germination space, lighting, soil characteristics. Each type of seed has a different germination period and requires particular germination conditions [32].

Numerous studies have shown that different artificial treatments applied to seeds have the effect of improving the germination process. For example, Rifna et al. [33] have shown that ultrasonic treatment and UV radiation have a positive effect on germination. The ultrasound treatment applied to the seeds consisted of frequencies between 20 and $100 \mathrm{kHz}$ and an intensity of 10-1000 W/ $/ \mathrm{cm}^{2}$. The positive influence of ultrasound treatment is attributed to the improvement of water absorption by 
seeds. Ding et al. [34] have shown that an exposure to $25 \mathrm{kHz}$ ultrasound treatment for $5 \mathrm{~min}$ of red rice and brown rice seeds leads to an improved germination rate and improved functional properties of the flour obtained from these seeds. Porto et al. [35] also concluded that the ultrasound treatment of dry seeds improves the germination process.

The artificially induced germination process was used to obtain germinated seeds with superior properties in order to be incorporated into various food products being described in different studies. Studies have shown that when the artificial germination process was applied to the seeds, some preliminary treatments must be used in order to assure the optimal conditions to the germination process. For example, Kaczmarska et al. [36] obtained the germinated seeds after the following process described below. First, the seeds must be selected to eliminate any impurities or degenerated seeds. Then, the seeds need to be sanitized with a $3 \%$ hydrogen peroxide solution. Then, the seeds need to be rinsed with pure water to obtain a neutral $\mathrm{pH}$. After that, the seeds are soaked in pure water for $8 \mathrm{~h}$. After this, the seeds are placed in special containers for germination and covered with a special paper for germination. The germination time depends on the type of seed, and the germinating parameters should be carefully monitored (temperature of $22{ }^{\circ} \mathrm{C}$, relative humidity of air $50-60 \%$, access to daylight for $12 \mathrm{~h}$ and in the dark for $12 \mathrm{~h}$ ). After seed germination, a treatment for drying the seeds is applied in order to stop the evolution of the germination process.

\section{Germination Changes on the Sensory and Nutritional Characteristics of the Seeds}

\subsection{Sensory Characteristics}

Numerous studies have shown that germination has beneficial effects on the nutritional profile of the seeds subjected to this process. It is a low-cost and an effective technology to improve the nutritional quality of vegetables, by its antioxidant capacity, digestibility of proteins, by increasing its vitamin $C$ and $E$ content and by reducing its anti-nutritional factors [37]. Kaczmarska et al. [36] showed that the germination process had the effect of changing the flavor characteristics of seeds as lupine and soybean ones. Thus, they showed that after the germination process, the amount of volatile organic compounds such as 2-methylbutanal and dimethyltrisulfite increased, which had the effect of intensifying the seeds' flavor. At the same time, the sweet taste of the seeds was also intensified.

$\mathrm{Xu}$ et al. [38] have shown that in the case of the chickpea, the changes in the flavor profile became undesirable after a period of 4 days when the seeds were subjected to the germination process. It seems that a longer period of germination intensifies the specific flavor of beans in the case of lentils and chickpeas, and in the case of the chickpea the specific flavor of beans decreased and unpleasant aromas appeared. Additionally, the study showed that the aroma profile of the lentil and pea, after germination, was similar, and in the case of the chickpea flour the specific flavor of beans decreased, and unpleasant aromas appeared. The study of changes in the flavor profile during the germination process is desirable to successfully achieve the improvement of the nutritional profile of the seeds, without adversely affecting their flavor.

In general, with the increasing period of the germination time, the sensory profile of the cereals/legumes subjected to the germination process became more and more pronounced. Xu et al. [39] highlighted that the specific smell of beans became more pronounced in the case of chickpeas, lentils and peas, with the increase in the period in which the legumes were subjected to the germination process. They showed that three compounds involved in the formation of the sensory profile decreased in concentration with increasing germination time. This is due to the fact that germination degrades the endosperm, favoring the elimination of flavor compounds. A solution to reduce the specific aroma of beans would be the addition of antioxidants in the germination process.

Dueñas et al. [40] reported that the seeds' germination increased the amount of phenolic compounds and dietary fiber of the seeds, affecting its taste. These results were in agreement with those reported by $\mathrm{Xu}$ et al. [41] which concluded that phenolic compounds influenced the bread sensory quality in a significant way, taste being one of the main characteristics affected by them. They also concluded that 
bread samples with a high quantity of phenolic compounds presented a more astringent taste than the control sample. However, according to Gebski et al. [42] it seems that the dietary fiber did not affect in such a significant way the taste of the bread samples and therefore it may be concluded that the phenolic compounds has a higher impact on bread taste than the dietary fibers.

\subsection{Nutritional Characteristics}

The main purpose of using the germinated seeds or of the flour obtained from them in the recipes of the food manufacture products is, as we mentioned above, the improvement of the nutritional characteristics of foodstuffs. The germination process leads, along with the physical changes of the seeds, to improvements in their nutritional profile.

For example, studies have shown that the germination process influences the fat content of the seeds. Thus, Xu et al. [39] concluded that the decrease in the fat content might be due to the increase in lipolytic activity during the germination process. Thus, lipid compounds are hydrolyzed to ensure seed development. However, reducing the amount of fat depends on the species undergoing the germination process. Some studies show that the ash content increased during the germination process, in the case of amaranth and rice. This was due to the decrease in the amount of soluble solid substances (such as starch and different types of sugars). Germination does not significantly affect the carbohydrate content, seeming that the amylose content decreases and the total sugar content increases. Due to the fact that by the germination process, the nutritional characteristics of seeds are improved, the germinated seeds can be successfully used in bakery products [18].

Bueno et al. [43] concluded that the germination process, in the case of soybeans, increases the content of free amino acids, sugars, phenolic compounds and its antioxidant potential. After $32 \mathrm{~h}$ of germination, the maximum antioxidant capacity was highlighted. The antioxidant capacity began to increase after $8 \mathrm{~h}$ of germination. Thus, it demonstrated the possibility of using germinated soy beans for the development of innovative foods with special properties, such as soy milk.

In the case of buckwheat seeds, germination has been shown to increase the total content of flavonoids, amino acids and reducing sugars. In contrast, the total protein and sugar content increased. At the same time, the content of vitamin $C$ and $B_{1}$ decreased. In the case of vitamins $B_{2}$ and $B_{6}$ there were no significant changes. Moreover, the value of the free radical-scavenging activities increased due to the increase in its antioxidant activity [44].

Lentil, soybean, lupine and beans flour are increasingly used to improve the nutritional properties of food. For this reason, current studies often highlight the effect of their germination, in order to see the possibilities of improving the sensory profile of food through germination. Lentils are a legume whose consumption has been shown to have many health benefits, including reducing the risk of cancer due to its content in anticarcinogenic substances such as lectins, glycosidic saponins, bioactive peptides which include protease inhibitors, fermentable fibers and oligosaccharides. The high polyphenol content in lentils has anti-tumor action. [45]. Lentil are of high interest to be incorporated into various foods because it contains no gluten. It has a high protein content, namely $30.65 \mathrm{~g} / 100 \mathrm{~g}$. This content increased during germination to $33.60 \mathrm{~g} / 100 \mathrm{~g}$. The total starch content in the case of lentils germinated decreased during this process. At the same time, the germination process had the effect of increasing the viscosity of the lentil flour to a value of $1061 \mathrm{cP}$ even after the first 2 days of germination. After germination, the water absorption capacity was highly improved.

In the case of lentils, the following changes were noticed after six days of germination: an increase in the amount of ash and a decrease in the amount of starch, lipids and amylose. The decrease in the amount of starch is due to the release of enzymes from the outer shell of seed ( $\alpha$-amylase, glucosidase, dextranase) and from endosperm ( $\beta$-amylase). The presence of hydrolytic enzymes causes the starch conversion to oligosaccharides or monosaccharides, which, leads to a decrease in the amount of starch. The starch amount was reduced from $41.02 \mathrm{~g} / 100 \mathrm{~g}$ to $34.96 \mathrm{~g} / 100 \mathrm{~g}$, after six days of germination, according to a study by $\mathrm{Xu}$ et al. [46]. The decreases in the amount of lipids content are due to their use by the seeds during the development process. Thus, it was noted that during germination, triglycerol 
is hydrolyzed by enzymes to release fatty acids. They will be oxidized at the level of the cytosol and mitochondria to release the energy needed in the germination process [47]. Fouad and Rehab [48] also have highlighted that the germination of lentil seeds at a temperature of $25^{\circ} \mathrm{C}$ for $3-6$ days, in dark conditions, leads to a decrease in lipid content.

In relation to the lentil flour properties, some changes due to the germination process were also reported. The viscosity of lentil flour increased after three days of germination. After the germination time continued, the viscosity registered a downward trend [49]. This may be due to the fact that the enzymes had hydrolyzed a significant amount of amylose and amylopectin, which resulted in the beginning of a damaged network starch. This also could lead to an increase in the starch digestibility [50]. Studies have shown that germination improves the water absorption capacity of lentil flour, namely the flour ability to absorb water, after 2-4 days of germination. This is probably explained by the macronutrient structural changes, but also by the fact that the starch in the germinated seeds changes its structure. At the same time, during the germination process the amount of melatonin in lentils increases. This increase occurs with the increase in root size [37]. Therefore, it seems that the germination process significantly improves lentil's nutritional characteristics, such as its antioxidant capacity, leading to the obtaining of an ingredient with a functional role which may be used to obtain innovative and functional food products. Taking into account that lentil is a gluten-free legume, it could be also successfully used to obtain foodstuffs for people suffering from celiac disease [46].

Another legume that is of interest in the food industry because it has special properties for improving human health is chickpeas. Recently, there has been a special interest in chickpeas because they are an ideal source of proteins, fibers, carbohydrates as well as minerals and thus help maintain a balanced diet. For vegetarians, chickpeas are an ideal source of proteins. Moreover, the content of allergens from it is low. At the same time, chickpeas could be considered an alternative to soy. Studies have shown an in vitro digestibility for chickpeas between $48 \%$ and $89.01 \%$, higher than for soybeans and beans [51].

In the case of chickpeas, germination has been shown to increase the total flavonoid content, polyphenolic compounds that have antioxidant action. The total flavonoid content increases after germination, from 0.22 to $0.42 \mathrm{~g} / \mathrm{kg}$, at a germination temperature of $30^{\circ} \mathrm{C}$. At a germination temperature of more than $10^{\circ} \mathrm{C}$, the total flavonoids content was $0.38 \mathrm{~g} / \mathrm{kg}$. Thus, it can be concluded that the germination temperature influences the increase in the flavonoid content. This increase depends on the seed response to different stressors, biotic and abiotic [52]. However, the change in the total flavonoid content during germination is different for each type of seed. This change is based on the seed characteristics, the class of which it belongs to and their hardness [53].

Chickpea germination, as outlined by studies to date, does not significantly influence its content in proteins, lipids, fiber, ash and carbohydrates. However, this process increases the amount of ascorbic acid. This content increases from $1.9 \mathrm{mg} / 100 \mathrm{~g}$ to $9.4 \mathrm{mg} / 100 \mathrm{~g}$ (after a germination period of $24 \mathrm{~h}$ ) and to $15.6 \mathrm{mg} / 100 \mathrm{~g}$ (after a germination period of $48 \mathrm{~h}$ ). At the same time, an increase in some essential amino acids was noticed after germination. For example, the contents of threosine, lysine, leucine, valine and isoleucine increased after $24 \mathrm{~h}$ of germination, and in the case of some of them their contents decreased with increasing germination time to $48 \mathrm{~h}$. The highest increase was in the case of lysine [54]. However, studies have shown that only the germination of chickpeas in optimal conditions leads to the nutritional improvement of chickpeas. Thus, the monitoring of the temperature and germination time is absolutely necessary in order to achieve the desired nutritional improvement. A study carried out by Domínguez-Arispuro et al. [55] concluded that the optimal parameters for the germination process in the case of chickpeas were: $27.5-35^{\circ} \mathrm{C}$ and $125-240 \mathrm{~h}$. The parameters of the germination process in which the nutritional compounds considered (polyphenol content, the total content of flavonoids, antioxidant activity) recorded the highest values were of $33.7^{\circ} \mathrm{C}$ and $171 \mathrm{~h}$. Under these conditions, it was shown that the content of dietary fiber significantly increased in the case of chickpeas. Moreover, after the germination process, a significant increase in ferulic and ellagic acids was noticed, which have antioxidant effects. At the same time, the germination conducted led to a significant increase in protein 
content (germination took place at $33.7^{\circ} \mathrm{C}$ for $171 \mathrm{~h}$ ) [55]. The increase in protein content has been attributed to the loss of dry matter, especially in carbohydrates, during the process of seed respiration during germination. In addition, a decrease in lipid content was observed, due to its consumption as an energy source in the germination process [56].

Another legume that occupies a special place among vegetarians is soy. At the same time, soy consumption has various health benefits. Watanabe and Uehara [57] have shown that isoflavones from soy contents are nonsteroidal phytoestrogenic and antioxidative diphenolic compounds that have a positive role in preventing diseases such as osteoporosis, cardiovascular disease, postmenopausal syndrome [57,58]. Soy protein is also an important source of amino acids [59]. A study by Miglani and Sharma [60] indicated that the content of soy phenolic constituents is significantly influenced by germination time and temperature. The germination process changes the structure of the polysaccharide wall of the seed cell wall. Megat et al. [61] studied the influence of the germination process on soybean fibers and showed that the total content of dietary fiber (soluble and insoluble) increased significantly compared to ungerminated seeds. Thus, the germination process can be used as a method to improve the dietary fiber content of soybeans, this having favorable health implications. In the case of soybeans, it has also been shown that the germination process leads to a significant increase in the content of phenols and flavonoids. Its maximum amount was determined at seven days of germination [62]. Regarding green soybeans, after germination, there was a decrease of $14 \%$ in protein, $37 \%$ in lipids, $22 \%$ in carbohydrates and $16 \%$ in ash, according to a study by Chen and Chang [63]. Furthermore, in some studies, following the germination of soybean seeds, there was a decrease in lipid content and the activity of lipoxygenase- 1 and lipoxygenase- 3 . The variation of the last two depended on the germination time. The longer the germination time, the lower their value was due to the degradation of lipoxygenase which plays an important role in the oxidation of unsaturated fatty acids, such as linoleic, linolenic, arachidonic. Following germination, the content of trypsin inhibitors also decreased. They played an important role in decreasing the digestibility of proteins by inactivating trypsin. The highest decrease in trypsin inhibitors was recorded after two days of germination [64]. At the same time, it has been shown that the germination process has the effect of reducing the glycemic index. This is because arabinose, the dominant polysaccharide in soy, is used in the germination process as an energy source or for macromolecule biosynthesis. Thus, it can be concluded that germination decreases the activity of lipoxygenase and trypsin inhibitors, which leads to a decrease in the formation of unpleasant flavor compounds and an increase in the proteins' digestibility [65].

Another seed that was subjected to the germination process to be incorporated into the manufacturing recipes of various foods was lupine. Lupine belongs to the genus Lupinus, and three species of this genus are used in human consumption. Consumers should be aware that its consumption can cause allergic reactions [66]. Lately, the interest in using lupine flour in different foods has increased a lot due to its nutritional value. Lupine is high in protein and fiber and low in fat [67]. Studies show that lupine seeds have anti-inflammatory action [68]. Olkowski [69] reported that lupine seeds contain a higher amount of protein than all other grain legumes. Lupine seeds have a high lysine content [70], which contributes to extending the shelf life of bakery products in which lupine flour has been used [71]. The germination of lupine seeds leads to increased melatonin, total phenol and flavonoid contents and antioxidant activity [72].

The positive effect of the germination process on the nutritional value of seeds has been highlighted by various studies also in the case of beans. Beans are of interest because they have a high nutritional value and their consumption has positive effects on human health. Common beans are rich in protein and various macronutrients, especially zinc and iron [73]. Iron has an important role in the human body because it is used by hemoglobin to transport oxygen to the body [74]. Zinc has an important role in cell division, immune system, wound healing process, and carbohydrate metabolism [75]. Beans contain a significant amount of fiber [76-78]. Epidemiological studies have shown that eating beans reduces the risk of cardiovascular disease, diabetes, cancer, helps control blood sugar levels and have antioxidant action [79]. The germination process of beans has the effect of improving the 
bioavailability and potential health benefits of starch and the protein fractions contained in them. Germination causes a decrease in the starch content of beans. This reduction can be attributed to the enzymatic hydrolysis of this polymer by the enzymes activity during germination [80]. The amylose content of black beans was determined to be $26 \mathrm{~g} / 100 \mathrm{~g}$, and during germination this content decreases to $20 \mathrm{~g} / 100 \mathrm{~g}$ [81]. This decrease is due to the amylolytic capacity of the beans' own enzymes [82].

\section{The Use of Germinated Seeds in the Bread Making Recipe}

In order to improve the bread quality from the nutritional point of view, an attempt was made to incorporate flours from different germinated seeds in its recipe. At the same time, the effect brought by this addition on the sensory and physico-chemical profile of the bread was analyzed, as were the changes made on the rheological characteristics of the dough samples. However, there are few studies on how the addition of germinated seeds influences the dough characteristics and bread quality.

The addition of flour from germinated seeds is recommended to be used in bread making recipes in order to improve its nutritional value [83]. This addition also has an influence on the characteristics of the dough, but also on the quality characteristics of the bread [84]. In general, the studies showed a positive influence of the addition of germinated seeds flour on the rheological characteristics of the dough samples. For example, in general, the addition increases the water absorption values [85]. However, there are also some types of germinated seeds flour whose incorporation into the bread making recipe has led to a decrease in the water absorption value. Therefore, for the use of a type of germinated seed flour in the bread making recipe, it is important to monitor its influence on this characteristic because the water absorption value influences in a significant way the dough behavior during the technological process of bread making.

\subsection{The Influence of the Addition of Germinated Seeds on the Wheat Flour Dough}

Regarding germinated soybean flour, Shin et al. [86] highlighted the fact that its addition in the dough recipe increases the water absorption value. In addition, when the flour obtained from germinated soybean was incorporated in wheat flour dough, its volume increased during the fermentation process compared to the addition of ungerminated soybean flour, steamed soybean flour and roasted soybean flour. Rasales-Juárez et al. [87] concluded that the farinographic values such as dough development time and dough stability slightly increased when germinated soybean flour was incorporated in the dough recipe. This was attributed to the increase in the enzymatic activity from the dough system or to the hydrophilic components due to the germination process. Thus, the authors pointed out the possibility of using flour from germinated soybean in wheat flour which contains a low amount of protein which may improve the characteristics of the wheat flour dough. Additionally, it seems that the germinated seed flour addition influences the viscosity of the wheat flour dough. This may be due to the fact that soy contains a significant amount of carbohydrates (including pentosans) that could influence the flour's ability to absorb water. Some studies have shown that a high level of pentosans led to a sticky dough [88] and to a delay in the development of gluten [89]. However, more studies on the possible interfering effects between soy carbohydrates and wheat flour on dough rheology would be necessary [87].

In the case of the addition of germinated bean flour, Morard et al. [90] have shown that the water absorption increased with the increasing amount of its addition in wheat flour. Aprodu et al. [91] highlighted that the addition of germinated bean flour led to an increase in the water solubility index of the flour mix (wheat and germinated beans). It seems that the addition of germinated bean flour improved the dough rheological properties due to the fact that its viscoelasticity was improved. An improvement in the dough volume was also observed during the fermentation in which germinated bean flour was incorporated.

Guardanelli et al. [92] highlighted the fact that the addition of germinated seed flour led to an increase in the dough moisture. This increase was also reported in a previous study by Bojnanská and Smitalová [93]. The authors noticed that the dough consistency increased for the samples in which 
germinated seed flour was incorporated compared to the control sample in which no germinated seed flour was added. In addition to the increase in the germinated seed flour addition, the dough adhesiveness and cohesiveness increased. The viscosity of the dough with the addition of germinated seed flour was also increased probably due to the depolymerization process during germination. Therefore, the addition of germinated seed flour influenced dough rheology and the physicochemical properties of the dough, also improving dough elasticity [94]. Therefore, germinated seed flour can be used to obtain dough with good rheological properties, especially if it is also considered to improve it from a nutritional point of view [95].

In the literature, there are studies that show that the addition of germinated wheat flour in the bread making recipe has the effect of increasing the mixing time of the dough obtained and also strengthens it. Furthermore, it was noticed that an increase in the lipolytic activity from the dough system may lead to a decrease in the shelf life of the mix samples. In general, an addition of less than $10 \%$ germinated seed flour has a positive effect on the dough rheological properties. A higher level of germinated seed flour addition leads to a decrease in the volume of the dough samples which also leads to a decrease in the bread samples' loaf volume [96]. Moreover, some studies have shown that subjecting wheat grains to germination reduces the quantity of peptides which play an important role in triggering celiac disease. This fact highlights another benefit of the germination process on the human body [97].

In general, different studies have reported that an amount of germinated seeds of up to $10 \%$ addition in wheat flour has no negative effects on the dough's rheological properties. According to these studies, it seems that a $5 \%$ addition of germinating seeds has led to optimum wheat flour dough rheological properties $[96,98,99]$.

\subsection{The Influence of the Addition of Germinated Seeds on the Bread Quality}

Millar et al. [99] highlighted that the addition of germinated pea flour decreases the loaf volume of the bread samples. Fernandez and Berry [100] also reported that the addition of germinated chickpea flour influences in a negative way the loaf volume of the bread samples. However, Levent et al. [101] reported that the addition of $10 \%$ germinated chickpea flour has improved the characteristics of the bread samples obtained probably due to the increase in the hydrolytic enzymatic activity from the dough system and its soluble components. An addition of $20 \%$ germinated chickpea flour had the effect of decreasing the loaf volume of bread samples. In addition, the color of the bread samples was not affected by a $10 \%$ addition, but was significantly influenced by a $20 \%$ addition [102]. Guardado-Félix et al. [99] highlighted the fact that the addition of germinated chickpea flour decreases the loaf volume of bread to a level of a $7-13 \%$ addition. At the same time, the bread obtained with germinated chickpea flour has a darker crust, darker crumb and a higher density. The textural parameters are not influenced in a significant way. All chickpea flours increased with more than $2 \%$ the water absorption values and consequently the bread yield decreases by between 7 and $13 \%$ as does the loaf volume of the bread samples.

Shin et al. [86] highlighted the fact that the one with the addition of germinated soybean flour had a higher loaf volume than the bread obtained without germinated seed flour addition. This is due to the fact that, as a result of the germination process, the solubility of the proteins increased, which led to a better emulsification and foaming capacity [102]. Therefore, bread samples made with germinated soybean flour presented better quality characteristics.

The influence of the addition of germinated soybean flour in wheat flour on the bread crumb and bread crust was highlighted by Rasales-Juárez et al. [87], who reported that the bread crust was less yellow when germinated soybean flour was added in the bread recipe. It seems that compared with the addition of ungerminated soybean flour, the addition of germinated flour in a bread recipe had the effect of improving the color of the samples, making the crumb whiter and without changing in a negative way the color of the crust samples. Rosales-Juárez et al. [87] have also reported that the addition of germinated soybean flour improved the loaf volume of bread samples. 
In general, studies have shown a negative influence of a high addition (higher than $10 \%$ ) on the quality of bread [103] whilst an addition of up to $3 \%$ of germinated soy flour has a positive effect. The positive effect was due to the enzymes from the germinated flour (lipoxygenase, amylase, lipase, alpha galactosidase), but also to the content of lecithin and ascorbic acid which considerably increases during the germination process. It was also reported that germinated soybean seeds can be successfully used as substitutes for chemical additives often used in the bakery industry, due to its high content in ascorbic acid, lecithin and enzymes, often used as additives in bread making [104].

Al Omari et al. [105] studied the influence of wheat flour substitution with germinated lupine flour on the characteristics of the bread obtained and reported that a maximum substitution of $20 \%$ germinated lupine flour does not significantly influence the sensory profile of the bread samples. From all the sensory characteristics, the color parameter was the most influenced due to the presence of lupine seeds in yellow pigments, lutein and zeaxanthin, but also to the high lysine content from germinated lupine, lysine being the most reactive amino acid of the Maillard reaction. These results were similar to those reported by Obeidat et al. [106]. In addition, it was reported that as the amount of germinated lupine flour increased, the loaf volume of bread samples decreased. However, it seems that a level of $5 \%$ germinated lupine flour addition in the bread recipe does not significantly influence the loaf volume of bread samples. Moreover, in order to preserve the quality characteristics of the bread samples, in terms of freshness characteristics, a maximum substitution of wheat flour with germinated lupine flour of $10 \%$ was allowed. These results were similar with those reported by Abdul Hussain et al. [107]. According to the reported studies, it seems that germinated lupine flour can be used in bread making recipes in order to improve its quality from the nutritional and technological point of view. In order to obtain bread samples of a good quality, the recommended levels of germinated lupine flour addition in wheat flour was up to $10 \%$ [108].

Although the beans germination has led to a significant improvement in its nutritional profile [109], few studies have been made on the addition of them in bread making and the effect on bread quality. Morard et al. [90] highlighted that the addition up to a level of 5\% germinated bean flour does not affect in a negative way the loaf volume of the bread. The loaf volume of the bread decreased, however, when high levels of germinated bean flour were incorporated in wheat flour. Moreover, the color of the bread crust decreased in intensity as the addition level of germinated bean flour increased.

The addition of germinated wheat flour up to a level of 50\% addition in the wheat flour of a strong quality for bread making improves the loaf volume and porosity of the bread samples, as highlighted by Marti et al. [109]. This improvement was probably due to the increase in $\alpha$-amylase content from the dough system due to the germination process of wheat flour. The addition also led to bread samples with a darker crust and a reddish tint. This was due to the Maillard reaction which is more intense in bread samples with germinated wheat flour. The higher level of $\alpha$-amylase from the dough system has also been conducted for bread samples with a higher loaf volume.

It is well known that through the germination process, the amount of dietary fibers and polyphenolic compounds from the vegetables increases [108]. From the bread quality point of view, it seems that these compounds from the germinated vegetables have a high influence on its characteristics. It has been reported that the dietary fibers do not significantly affect the bread sensory characteristics such as taste and flavor but it had a significant effect on loaf volume [110,111]. Almeida et al. [110] reported that even at $20 \%$ fiber addition in wheat flour, the sensory characteristics of bread such as taste and flavor were not significantly affected. Moreover, they reported that the addition of fibers in wheat flour led to an improvement in bread quality by an increase in freshness due to the increase in the water absorption capacity and moisture retention. From the color point of view, it seems that depending on its type, fibers addition may influence this characteristic. For example, the wheat bran led to a decrease in the bread samples' brightness. In general, studies have shown that there was no significant negative influence of the addition of fiber (in the form of carob fiber, inulin and pea fiber type, etc.) on the overall quality and acceptability of the bread obtained [112]. Fendri et al. [113] concluded that the addition of fibers extracted from the pea and bean improved the 
textural profile of the bread samples and changes the dough's textural properties. They reported a decrease in the bread samples hardness and an increase in the cohesiveness and adhesiveness of the wheat flour dough. However, regarding the phenol effect point of view on bread making, it seems that its addition affects the bread quality in a more significant way. It was highlighted that the phenolic compounds' addition decreased the loaf volume and increased the bread hardness value $[41,114]$. It has also been reported that the polyphenols' addition affects starch gelatinization process leading to an increase in the gelatinization temperature [115] influencing starch retrogradation and increasing bread freshness [116]. According to these studies, it has been concluded that the addition of different ingredients in bread making with a high amount of polyphenol content may be a good alternative for substituting synthetic chemical additives, these being considered natural dyes, preservatives and antioxidant materials.

\section{Conclusions and Perspectives}

Germinated legumes can be successfully used in various food manufacturing recipes, especially in order to improve the nutritional value of these products. This way, the germination process can be successfully used to improve wheat flour in order to obtain healthier bakery products. In addition, the flour obtained from germinated seeds can be used as a substitute for different chemical additives that are often used in the bakery industry due to its high content of enzymes, ascorbic acid, lecithin, etc. However, even though there are many publications in the international literature on the influence of the addition of different types of legume flour in the bread making recipe, there are few studies on the addition of legume flour in a germinated form on bread making. The present study sought new alternatives for bread making improvement, underlining how different types of legumes in a germinated form can improve the dough's rheological characteristics and the final quality of bread.

Author Contributions: D.A. and G.G.C. contributed equally to the study design, collection of data, development of the sampling, analyses, interpretation of results, and preparation of the paper. All authors have read and agreed to the published version of the manuscript.

Funding: This research received no external funding.

Acknowledgments: This work was supported by a grant of the Romanian Ministry of Research and Innovation, CNCS-UEFISCDI, project number PN-III-P1-1.1-TE-2019-0892, within PNCDI III.

Conflicts of Interest: The authors declare no conflict of interest.

\section{References}

1. Steinbrecher, T.; Leubner-Metzger, G. The biomechanics of seed germination. J. Exp. Bot. 2017, 68, 765-783. [CrossRef] [PubMed]

2. Nonogaki, M.; Nonogaki, H. Germination. Encycl. Appl. Plant Sci. 2017, 1, 509-512.

3. Li, Q.F.; Zhou, Y.; Xiong, M.; Ren, X.Y.; Han, L.; Wang, J.D.; Zhang, C.Q.; Fan, X.L.; Liu, Q.Q. Gibberellin recovers seed germination in rice with impaired brassinosteroid signalling. Plant Sci. 2020, 293, 110435. [CrossRef] [PubMed]

4. Ma, M.; Zhang, H.; Xie, Y.; Yang, M.; Tang, J.; Wang, P.; Yang, R.; Zhenxin, G. Response of nutritional and functional composition, anti-nutritional factors and antioxidant activity in germinated soybean under UV-B radiation. LWT Food Sci. Technol. 2020, 118, 108709. [CrossRef]

5. Ohanenye, I.C.; Tsopmo, A.; Ejike, C.E.C.C.; Udenigwe, C.C. Germination as a bioprocess for enhancing the quality and nutritional prospects of legume proteins. Trends Food Sci. Technol. 2020, 101, 213-222. [CrossRef]

6. EL-Suhaibani, M.; Ahmed, M.A.; Osman, M.A. Study of germination, soaking and cooking effects on the nutritional quality of goat pea (Securigera securidaca L.). J. King Saud Univ. Sci. 2020, 32, 2029-2033. [CrossRef]

7. Xu, L.; Chen, L.; Yang, N.; Chen, Y.; Wu, F.; Jin, Z.; Xu, X. Impact of germination on nutritional and physicochemical properties of adlay seed (Coixlachryma-jobi L.). Food Chem. 2017, 229, 312-318. [CrossRef]

8. Singh, A.; Sharma, S. Bioactive components and functional properties of biologically activated cereal grains: A bibliographic review. Crit. Rev. Food Sci. 2017, 57, 3051-3071. [CrossRef] 
9. Sokrab, A.M.; Mohamed-Ahmed, I.A.; Babiker, E.E. Effect of germination on antinutritional factors, total, and extractable minerals of high and low phytate corn (Zea mays L.) genotypes. J. Saudi Soc. Agric. Sci. 2012, 11, 123-128. [CrossRef]

10. Sangronis, E.; Machado, C.J. Influence of germination on the nutritional quality of Phaseolus vulgaris and Cajanus cajan. LWT Food Sci. Technol. 2007, 40, 116-120. [CrossRef]

11. Ma, Z.; Boye, J.Y.; Hu, X. Nutritional quality and techno-functional changes in raw, germinated and fermented yellow field pea (Pisum sativum L.) upon pasteurization. LWT Food Sci. Technol. 2018, 92, 147-154. [CrossRef]

12. Han, A.; Arijaje, E.O.; Jinn, J.R.; Mauromoustakos, A.; Wang, Y.J. Effects of germination duration on milling, physicochemical, and textural properties of medium- and long-grain rice. Cereal Chem. 2016, 93, 39-46. [CrossRef]

13. Chu, C.; Du, Y.; Yu, X.; Shi, J.; Yuan, X.; Liu, X.; Liu, Y.; Zhang, H.; Zhang, Z.; Yan, N. Dynamics of antioxidant activities, metabolites, phenolic acids, flavonoids, and phenolic biosynthetic genes in germinating Chinese wild rice (Zizania latifolia). Food Chem. 2020, 318, 126483. [CrossRef] [PubMed]

14. Aisyah, S.; Vincken, J.P.; Andini, S.; Mardiah, Z.; Gruppen, H. Compositional changes in (iso)flavonoids and estrogenic activity of three edible Lupinus species by germination and Rhizopus-elicitation. Phytochemistry 2016, 122, 65-75. [CrossRef]

15. Ujiroghene, O.J.; Liu, L.; Zhang, S.; Lu, J.; Zhang, C.; Lv, J.; Pang, X.; Zhang, M. Antioxidant capacity of germinated quinoa-based yoghurt and concomitant effect of sprouting on its functional properties. LWT Food Sci. Technol. 2019, 116, 108592. [CrossRef]

16. Agdel-Aty, A.M.; Salama, W.H.; Fahmy, A.S.; Mohamed, S.A. Impact of germination on antioxidant capacity of garden cress: New calculation for determination of total antioxidant activity. Sci. Hortic. 2019, 246, 155-160. [CrossRef]

17. Rasera, G.B.; Hilkner, M.H.; de Soares-Castro, R.J. Free and insoluble-bound phenolics: How does the variation of these compounds affect the antioxidant properties of mustard grains during germination? Food Res. Int. 2020, 133, 109115. [CrossRef]

18. Cornejo, F.; Novillo, G.; Villacrés, E.; Rosello, C.M. Evaluation of the physicochemical and nutritional changes in two amaranth species (Amaranthus quitensis and Amaranthus caudatus) after germination. Food Res. Int. 2019, 121, 933-939. [CrossRef]

19. Gong, K.; Chen, L.; Li, X.; Sun, L.; Liu, K. Effects of germination combined with extrusion on the nutritional composition, functional properties and polyphenol profile and related in vitro hypoglycemic effect of whole grain corn. J. Cereal Sci. 2018, 83, 1-8. [CrossRef]

20. Padmashree, A.; Negi, N.; Handu, S.; Khan, M.A.; Semwal, A.D.; Sharma, G.K. Effect of Germination on Nutritional, Antinutritional and Rheological Characteristics of Quinoa (Chenopodium quinoa). Def. Life Sci. J. 2019, 4, 55-60. [CrossRef]

21. Polat, H.; Capar, T.D.; Inanir, C.; Ekici, L.; Yalcin, H. Formulation of functional crackers enriched with germinated lentil extract: A Response Surface Methodology Box-Behnken Design. LWT Food Sci. Technol. 2020, 123, 109056. [CrossRef]

22. Patel, M.M.; Venkateswara Rao, G. Effect of untreated, roasted and germinated black gram (phaseolus mungo) flours on the physico-chemical and biscuit (cookie) making characteristics of soft wheat flour. J. Cereal Sci. 1995, 22, 285-291. [CrossRef]

23. Chavan, M.; Gat, Y.; Harmalkar, M.; Wagnmare, R. Development of non-dairy fermented probiotic drink based on germinated and ungerminated cereals and legume. LWT Food Sci. Technol. 2018, 91, 339-344. [CrossRef]

24. Jiménez, D.; Lobo, M.; Irigaray, B.; Grompone, M.A.; Sammán, N. Oxidative stability of baby dehydrated purees formulated with different oils and germinated grain flours of quinoa and amaranth. LWT_Food Sci. Technol. 2020, 127, 109229. [CrossRef]

25. Kaczmarska, K.T.; Chandra-Hioe, M.V.; Frank, D.; Arcot, J. Enhancing wheat muffin aroma through addition of germinated and fermented Australian sweet lupin (Lupinus angustifolius L.) and soybean (Glycine max L.) flour. LWT Food Sci. Technol. 2018, 96, 205-214. [CrossRef]

26. Kaur, A.; Kaur, R.; Bhise, S. Baking and sensory quality of germinated and ungerminated flaxseed muffins prepared from wheat flour and wheat atta. J. Saudi Soc. Agric. Sci. 2020, 19, 109-120. [CrossRef]

27. Cáceres, P.J.; Peñas, E.; Martínez-Villaluenga, C.; García-Mora, P.; Frías, J. Development of a multifunctional yogurt-like product from germinated brown rice. Food Sci. Technol. 2019, 99, 306-312. [CrossRef] 
28. Park, K.M.; Oh, S.H. Production of yogurt with enhanced levels of gamma-aminobutyric acid and valuable nutrients using lactic acid bacteria and germinated soybean extract. Bioresour. Technol. 2007, 98, 1675-1679. [CrossRef]

29. Zhang, H.; Zhou, K.Z.; Wang, W.Q.; Liu, S.J.; Song, S.Q. Proteome analysis reveals an energy-dependent central process for Populus $\times$ canadensis seed germination. J. Plant Physiol. 2017, 213, 134-147. [CrossRef]

30. Eckelmann, D.; Kusari, S.; Spiteller, M. Spatial profiling of maytansine during the germination process of Maytenus senegalensis seeds. Fitoterapia 2017, 119, 51-56. [CrossRef]

31. Dai, W.; Wang, T.; Wang, C. Effects of interspecific interactions on seed germination between dominant species in the Yangtze River Estuary. Estuar Coast Shelf S. 2020, 232, 106483. [CrossRef]

32. Bubel, N.; Nick, J. The New Seed-Starters Handbook; Rodale Wellness: Allentown, PA, USA, 2018.

33. Rifna, E.J.; Ratish-Ramanan, K.; Mahendran, R. Emerging technology applications for improving seed germination. Trends Food Sci. Tech. 2019, 86, 95-108. [CrossRef]

34. Ding, J.; Hou, G.G.; Dong, M.; Xiong, S.; Zhao, S.; Feng, H. Physicochemical properties of germinated dehulled rice flour and energy requirement in germination as affected by ultrasound treatment. Ultrason. Sonochem. 2018, 41, 484-491. [CrossRef] [PubMed]

35. Porto, C.L.; Ziuzina, D.; Los, A.; Boehm, D.; Palumbo, F.; Favia, P.; Tiwari, B.; Bourke, P.; Cullen, P.J. Plasma activated water and airborne ultrasound treatments for enhanced germination and growth of soybean. Innov. Food Sci. Emerg. 2018, 49, 13-19. [CrossRef]

36. Kaczmarska, K.T.; Chandra-Hioe, M.V.; Frank, D.; Arcot, J. Aroma characteristics of lupin and soybean after germination and effect of fermentation on lupin aroma. LWT Food Sci. Technol. 2018, 87, 225-233. [CrossRef]

37. Aguilera, Y.; Herrera, T.; Liébana, R.; Rebollo-Hernanz, M.; Sanchez-Puelles, C.; Martín-Cabrejas, M.A. Impact of melatonin enrichment during germination of legumes on bioactive compounds and antioxidant activity. J. Agric. Food Chem. 2015, 63, 7967-7974. [CrossRef]

38. Xu, M.; Jin, Z.; Lan, Y.; Rao, J.; Chen, B. HS-SPME-GC-MS/olfactometry combined with chemometrics to assess the impact of germination on flavor attributes of chickpea, lentil, and yellow pea flours. Food Chem. 2019, 280, 83-95. [CrossRef]

39. Xu, M.; Jin, Z.; Gu, Z.; Rao, J.; Bingcan, C. Changes in odor characteristics of pulse protein isolates from germinated chickpea, lentil, and yellow pea: Role of lipoxygenase and free radicals. Food Chem. 2020, 314, 126184. [CrossRef]

40. Dueñas, M.; Sarmento, T.; Aguilera, Y.; Benitez, V.; Mollá, E.; Esteban, R.M.; Martín-Cabrejas, M.A. Impact of cooking and germination on phenolic composition and dietary fiber fractions in dark beans (Phaseolus vulgaris L.) and lentils (Lens culinaris L.). LWT Food Sci. Technol. 2016, 66, 72-78. [CrossRef]

41. Xu, J.; Wang, W.; Li, Y. Dough properties, bread quality, and associated interactions with added phenolic compounds: A review. J. Funct. Foods 2019, 52, 629-639. [CrossRef]

42. Gębski, J.; Jezewska-Zychowicz, M.; Szlachciuk, J.; Kosicka-Gębska, M. Impact of nutritional claims on consumer preferences for bread with varied fiber and salt content. Food Qual. Prefer. 2019, 76, 91-99. [CrossRef]

43. Bueno, D.B.; Silva-Júnior, S.I.; Seriani Chiarotoo, A.B.; Cardoso, T.M.; Neto, J.A.; Lopes dos Reis, G.C.; Abreu Glória, M.B.; Tavano, O.L. The germination of soybeans increases the water-soluble components and could generate innovations in soy-based foods. LWT Food Sci. Technol. 2020, 117, 108599. [CrossRef]

44. Yiming, Z.; Hong, W.; Linlin, C.; Xiaoli, Z.; Wen, T.; Xinli, S. Evolution of nutrient ingredients in tartary buckwheat seeds during germination. Food Chem. 2015, 186, 244-248. [CrossRef] [PubMed]

45. Faris, M.I.E.; Mohammad, M.G.; Soliman, S. Lentils (Lens culinaris L.): A candidate chemopreventive and antitumor functional food. Funct. Foods Cancer Prev. Ther 2020, 99-120. [CrossRef]

46. Xu, M.; Jin, Z.; Simsek, S.; Hall, C.; Rao, J.; Chen, B. Effect of germination on the chemical composition, thermal, pasting, and moisture sorption properties of flours from chickpea, lentil, and yellow pea. Food Chem. 2019, 295, 579-587. [CrossRef] [PubMed]

47. Cornejo, F.; Caceres, P.J.; Martínez-Villaluenga, C.; Rosell, C.M. Effects of germination on the nutritive value and bioactive compounds of brown rice breads. Food Chem. 2015, 173, 298-304. [CrossRef]

48. Fouad, A.A.; Rehab, F.M.A. Effect of germination time on proximate analysis, bioactive compounds and antioxidant activity of lentil (Lens culinaris Medik) sprouts. Acta Sci. Pol. Technol. Aliment. 2015, 14, 233-246. [CrossRef] 
49. Ghumman, A.; Kaur, A.; Singh, N. Impact of germination on flour, protein and starch characteristics of lentil (Lens culinari) and horsegram (Macrotyloma uniflorum L.) lines. LWT Food Sci. Technol. 2016, 65, 137-144. [CrossRef]

50. Acevedo, B.A.; Thompson, C.M.B.; González-Foutel, N.S.; Chaves, M.G.; Avanza, M.V. Effect of different treatments on the microstructure and functional and pasting properties of pigeon pea (Cajanus cajan L.), dolichos bean (Dolichos lablab L.) and jack bean (Canavalia ensiformis) flours from the north-east Argentina. Int. J. Food Sci. Tech. 2017, 52, 222-230. [CrossRef]

51. Rachwa-Rosiak, D.; Nebesny, E.; Budryn, G. Chickpeas-Composition, Nutritional Value, Health Benefits, Application to Bread and Snacks: A Review. Crit. Rev. Food Sci. 2015, 8, 1137-1145. [CrossRef] [PubMed]

52. Mamilla, R.K.; Mishra, V.K. Effect of germination on antioxidant and ACE inhibitory activities of legumes. LWT Food Sci. Technol. 2017, 75, 51-58. [CrossRef]

53. Kigel, J.; Rosenthal, L.; Fait, A. Seed physiology and germination of grain legumes, Grain legumes. Handb. Plant Breed. 2015, 10, 327-363.

54. Fernandez, M.L.; Berry, J.M. Nutritional evaluation of chickpea and germinated chickpea flours. Plant Food Hum. Nutr. 1988, 38, 127-134. [CrossRef] [PubMed]

55. Domínguez-Arispuro, D.M.; Cuevas-Rodrı́guez, E.O.; Mila'n-Carrillo, J.; León-López, L.; Gutie'rrez-Dorado, R.; Reyes-Moreno, C. Optimal germination condition impacts on the antioxidant activity and phenolic acids profile in pigmented desi chickpea (Cicer arietinum L.) seeds. J. Food. Sci. Technol. 2018, 55, 638-647. [CrossRef]

56. El-Adawy, T.A. Nutritional composition and antinutritional factors of chickpeas (Cicer arietinum L.) undergoing different cooking methods and germination. Plant Food Hum. Nutr. 2002, 57, 83-97. [CrossRef]

57. Watanabe, S.; Uehara, M. Health Effects and Safety of Soy and Isoflavones. Role Funct. Food Secur. Glabal Health 2019, 379-394. [CrossRef]

58. Cao, Z.H.; Green-Johnson, J.M.; Buckley, N.D.; Lin, Q.Y. Bioactivity of soy-based fermented foods: A review. Biotechnol Adv. 2019, 37, 223-238. [CrossRef]

59. Ju, M.; Huang, G.; Shen, X.; Zhang, Y.; Jiang, L.; Sui, X. A novel pickering emulsion produced using soy protein-anthocyanin complex nanoparticles. Food Hydrocolloid. 2020, 99, 105329. [CrossRef]

60. Miglani, H.; Sharma, S. Impact on germination time and temperature on phenolics, bioactive compounds and antioxidant activity of different coloured soybean. Proc. Natl. Acad. Sci. India Sect. B Boil. Sci. 2016, 88, 175-184. [CrossRef]

61. Megat, R.M.R.; Azrina, A.; Norhaizan, M.E. Effect of germination on total dietary fibre and total sugar in selected legumes. Int. Food. Res. J. 2016, 23, 257-261.

62. Lee, A.L.; Yu, Y.P.; Hsieh, J.F.; Kuo, M.I.; Ma, Y.S.; Lu, C.P. Effect of germination on composition profiling and antioxidant activity of the polysaccharide-protein conjugate in black soybean [Glycine max (L.) Merr.]. Int. J. Biol. Macromol. 2018, 113, 601-606. [CrossRef] [PubMed]

63. Chen, Y.; Chang, S.K.C. Macronutrients, Phytochemicals, and Antioxidant Activity of Soybean Sprout Germinated with or without Light Exposure. J. Food Sci. 2015, 80, S1391-S1398. [CrossRef] [PubMed]

64. Joshi, P.; Varma, K. Effect of germination and dehulling on the nutritive value of soybean. Nutr. Food Sci. 2016, 46, 595-603. [CrossRef]

65. Maetens, E.; Hettiarachchy, N.; Dewettinck, K.; Horax, R.; Moens, K.; Moseley, D.O. Physicochemical and nutritional properties of a healthy snack chip developed from germinated soybeans. LWT Food Sci. Technol. 2017, 84, 505-510. [CrossRef]

66. Koeberl, M.; Sharp, M.F.; Tian, R.; Buddhadasa, S.; Clarke, D.; Roberts, J. Lupine allergen detecting capability and cross-reactivity of related legumes by ELISA. Food Chem. 2018, 256, 105-112. [CrossRef]

67. Cabello-Hurtado, F.; Keller, J.; Ley, J.; Sanchez-Lucas, R.; Jorrin-Novo, J.; Aïnouche, A. Proteomics for exploiting diversity of lupin seed storage proteins and their use as nutraceuticals for health and welfare. J. Proteom. 2016, 143, 57-68. [CrossRef]

68. Cruz-Chamorro, I.; Álvarez-Sánchez, N.; Millán-Linares, M.C.; Yust, M.M.; Pedroche, J.; Millán, F.; Lardone, P.J.; Carrera-Sánchez, C.; Guerrero, J.M.; Carrillo-Vico, A. Lupine protein hydrolysates decrease the inflammatory response and improve the oxidative status in human peripheral lymphocytes. Food Res Int. 2019, 126, 108585. [CrossRef]

69. Olkowski, B. Feeding high lupine based diets for broiler chickens: Effect of soybean meal substitution with yellow lupine meal at various time points of growth cycle. Livest. Sci. 2018, 218, 114-118. [CrossRef] 
70. El-Adawy, T.A.; Rahma, E.H.; El-Bedawey, A.A.; Gafar, A.F. Nutritional potential and functional properties of sweet and bitter lupin seed protein isolates. Food Chem. 2001, 74, 455-462. [CrossRef]

71. López, E.P.; Goldner, M.C. Influence of storage time for the acceptability of bread formulated with lupine protein isolate and added brea gum. LWT Food Sci. Technol. 2015, 64, 1171-1178. [CrossRef]

72. Saleh, H.M.; Hassan, A.A.; Mansour, E.H.; Fahmy, H.A.; El-Fath, A.; El-Bedawey, A.E. Melatonin, phenolics content and antioxidant activity of germinated selected legumes and their fractions. J. Saudi Soc. Agric. Sci. 2019, 18, 294-301. [CrossRef]

73. Philipo, M.; Ndakidemi, P.A.; Mbega, E.R. Environmental and genotypes influence on seed iron and zinc levels of landraces and improved varieties of common bean (Phaseolus vulgaris L.) in Tanzania. Ecol. Genet Genom. 2020, 15, 100056. [CrossRef]

74. UCSF Medical Center. Hemoglobin and Functions of Iron. Ucsf Heal. 2019. Available online: https: //www.ucsfhealth.org/education/hemoglobin-and-functions-of-iron (accessed on 2 May 2020).

75. Lokuruka, M.N.I. Role of zinc in human health with reference to African elderly: A review. AJFAND 2012, $12,6646-6664$.

76. Reverri, E.J.; Randolph, J.M.; Kappagoda, C.T.; Park, E.; Edirisinghe, I.; Burton-Freeman, B.M. Assessing beans as a source of intrinsic fiber on satiety in men and women with metabolic syndrome. Appetite 2017, 118, 75-81. [CrossRef]

77. Xia, Q.; Gu, N.; Liu, J.; Niu, Y.; Yu, L.L. Novel composite gels of gelatin and soluble dietary fiber from black bean coats with interpenetrating polymer networks. Food Hydrocolloid. 2018, 83, 72-78. [CrossRef]

78. Kutoš, T.; Golob, T.; Kač, M.; Plestenjak, A. Dietary fibre content of dry and processed beans. Food Chem. 2003, 80, 231-235. [CrossRef]

79. Hayat, I.; Ahmad, A.; Masud, T.; Ahmed, A.; Bashir, S. Nutritional and Health Perspectives of Beans (Phaseolus vulgaris L. ): An Overview. Crit. Rev. Food Sci. 2014, 54, 580-592.

80. Yin, Y.; Yang, R.; Gu, Z. Organ-specific proteomic analysis of NaCl-stressed germinating soybeans. J. Agric. Food Chem. 2014, 62, 7233-7244. [CrossRef]

81. Rosa-Millán, J.; Heredia-Olea, E.; Perez-Carrillo, E.; Guajardo-Flores, S.; Serna-Saldívar, S.R.O. Effect of decortication, germination and extrusion on physicochemical and in vitro protein and starch digestion characteristics of black beans (Phaseolus vulgaris L. ). LWT Food Sci. Technol. 2019, 102, 330-337. [CrossRef]

82. Menon, L.; Majumdar, S.D.; Ravi, U. Development and analysis of composite flour bread. J. Food Sci. Tech. 2015, 52, 4156-4165. [CrossRef]

83. Ertas, N.; Bilgiçli, N. Effect of different debittering processes on mineral and phytic acid content of lupin (Lupinus albus L.) seeds. J. Food Sci. Tech. 2014, 51, 3348-3354. [CrossRef]

84. Boukid, F.; Zannini, E.; Carini, E.; Vittadini, E. Pulses for bread fortification: A necessity or a choice? Trends Food Sci. Tech. 2019, 88, 416-428. [CrossRef]

85. Patrascu, L.; Aprodu, I.; Garnai, M.; Vasilean, I. Effect of germination and fermentation on the functionality of wheat-pulses flour mixtures. J. Biotechnol. 2018, 280, S52-S53. [CrossRef]

86. Shin, D.J.; Kim, W.; Kim, Y. Physicochemical and sensory properties of soy bread made with germinated, steamed, and roasted soy flour. Food Chem. 2013, 141, 517-523. [CrossRef]

87. Rosales-Juárez, M.; Beatriz-González-Mendoza, B.; López-Guel, E.C.; Lozano-Bautista, F.; Chanona-Pérez, J.; Gutiérrez-López, G.; Farrera-Rebollo, R.; Calderón-Domínguez, G. Changes on Dough Rheological Characteristics and Bread Quality as a Result of the Addition of Germinated and Non-Germinated Soybean Flour. Food Bioprocess. Tech. 2008, 1, 152-160. [CrossRef]

88. Ribotta, P.D.; Arnulphi, S.A.; León, A.E.; Añón, M.C. Effect of soybean addition on the rheological properties and breadmaking quality of wheat flour. J. Sci. Food Agric. 2005, 85, 1889-1896. [CrossRef]

89. Labat, E.; Rouau, X.; Morel, M.H. Effect of Flour Water-Extractable Pentosans on Molecular Associations in Gluten During Mixing. LWT Food Sci. Technol. 2002, 35, 185-189. [CrossRef]

90. Morard, M.M.; Leung, H.K.; Hsu, D.L. și Finney, P.L. Effect of Germination on Physicochemical and Bread-Baking Properties of Yellow Pea, Lentil, and Faba Bean Flours and Starches. Cereal Chem. 1980, 57, 390-396.

91. Aprodu, I.; Vasilean, I.; Muntenită, C. și Patrasu, L. Impact of broad beans addition on rheological and thermal properties of wheat flour based sourdoughs. Food Chem. 2019, 293, 520-528. [CrossRef]

92. Guardianelli, L.M.; Salinas, M.V.; Puppo, M.C. Hydration and rheological properties of amaranth-wheat flour dough: Influence of germination of amaranth seeds. Food Hydrocolloid. 2019, 97, 105242. [CrossRef] 
93. Bojňanská, T.; Šmitalová, J. Impact of amaranth (amaranth sp.) on technological quality of bakery products during frozen storage. JMBFS 2014, 3, 187-189.

94. Houben, A.; Götz, H.; Mitzscherling, M.; Becker, T. Modification of the rheological behavior of amaranth (Amaranthus hypochondriacus) dough. J. Cereal Sci. 2010, 51, 350-356. [CrossRef]

95. Poudel, R.; Finnie, S.; Rose, D.J. Effects of wheat kernel germination time and drying temperature on compositional and end-use properties of the resulting whole wheat flour. J. Cereal Sci. 2019, 86, 33-40. [CrossRef]

96. Boukid, F.; Prandi, B.; Vittadini, E.; Francia, E.; Sforza, S. Tracking celiac disease-triggering peptides and whole wheat flour quality as function of germination kinetics. Food Res. Int. 2018, 112, 345-352. [CrossRef]

97. Millar, K.A.; Barry-Ryan, C.; Burke, R.; McCarthy, S.; Gallagher, E. Dough properties and baking characteristics of white bread, as affected by addition of raw, germinated and toasted pea flour. Innov. Food Sci. Emerg. 2019, 56, 102189. [CrossRef]

98. Ouazib, M.; Garzon, R.; Zaidi, F.; Rosell, C.M. Germinated, toasted and cooked chickpea as ingredients for breadmaking. J. Food Sci. Tech. 2016, 53, 2664-2672. [CrossRef] [PubMed]

99. Guardado-Félix, D.; Lazo-Vélez, M.A.; Pérez-Carrillo, E.; Panata-Saquicili, D.E.; Serna-Saldívar, S.O. Effect of partial replacement of wheat flour with sprouted chickpea flours with or without selenium on physicochemical, sensory, antioxidant and protein quality of yeast-leavened breads. LWT Food Sci. Technol. 2020, 129, 109517. [CrossRef]

100. Farnandez, M.L.; Berry, J.W. Rheological properties of flour and sensory characteristics of bread made from germinated chickpea. Int. J. Food Sci. Tech. 1989, 24, 103-110. [CrossRef]

101. Levent, H.; Bilgiçli, N.; Ertaş, N. The assessment of leavened and unleavened flat breads properties enriched with wheat germ. Qual. Assur. Saf. Crop 2014, 7, 321-326. [CrossRef]

102. Mostafa, M.M.; Rahma, E.H.; Rady, A.H. Chemical and nutritional changes in soybean during germination. Food Chem. 1987, 23, 257-275. [CrossRef]

103. Diowksz, A.; Kordialik-Bogacka, E.; Ambroziak, W. Se-enriched sprouted seeds as functional additives in sourdough fermentation. LWT Food Sci. Technol. 2014, 56, 524-528. [CrossRef]

104. López-Guel, E.C.; Lozano-Bautista, F.; Mora-Escobedo, R.; Farrera-Rebollo, R.R.; Chanona-Pérez, J.; Gutiérrez-López, G.F.; Calderón-Domínguez, G. Effect of Soybean 7S Protein Fractions, Obtained from Germinated and Nongerminated Seeds, on Dough Rheological Properties and Bread Quality. Food Bioprocess Tech. 2012, 5, 226-234. [CrossRef]

105. al Omari, D.Z.; Abdul-Hussain, S.S.; Ajo, R.Y. Germinated lupin (Lupinus albus) flour improves Arabic flat bread properties. Qual. Assur. Saf. Crop 2016, 8, 57-63. [CrossRef]

106. Obeidat, B.A.; Abdul-Hussain, S.S.; al Omari, D.Z. Effect of addition of germinated lupin flour on the physiochemical and organoleptic properties of cookies. J. Food Process. Pres. 2013, 37, 637-643. [CrossRef]

107. Abdul-Hussain, S.S.; Ajo, R.Y.; Obeidat, B.A. Acceptability and chemical composition of thick flat bread supplemented with chickpea flour and isolated soy protein. In Proceedings of the 5th International Congress, Flour-Bread '09, 7th Croatian Congress of Cereal Technologists, Opatija, Croatia, 21-23 October 2009; pp. 280-287.

108. Setia, R.; Dai, Z.; Nickerson, M.T.; Sopiwnykb, E.; Malcolmsonc, L.; Ai, Y. Impacts of short-term germination on the chemical compositions, technological characteristics and nutritional quality of yellow pea and faba bean flours. Food Res. Int. 2019, 122, 263-272. [CrossRef] [PubMed]

109. Marti, A.; Cardone, G.; Ambrogina-Pagani, M.; Casiraghi, M.C. Flour from sprouted wheat as a new ingredient in bread-making. LWT Food Sci. Technol. 2018, 89, 237-243. [CrossRef]

110. Almeida, E.L.; Chang, Y.K.; Steel, C.J. Dietary fiber sources in bread: Influence on technological quality. LWT Food Sci. Technol. 2013, 50, 545-553. [CrossRef]

111. Ragaee, S.; Guzar, I.; Dhull, N.; Seetharaman, K. Effects of fiber addition on antioxidant capacity and nutritional quality of wheat bread. LWT Food Sci. Technol. 2011, 44, 2147-2153. [CrossRef]

112. Wang, J.; Rosell, C.M.; Benedito de Barber, C. Effect of the addition of different fibres on wheat dough performance and bread quality. Food Chem. 2002, 79, 221-226. [CrossRef]

113. Fendri, L.B.; Chaari, F.; Maaloul, M.; Kallel, F.; Abdelkafi, L.; Chaabouni, S.E.; Ghribi-Aydi, D. Wheat bread enrichment by pea and broad bean pods fibers: Effect on dough rheology and bread quality. LWT Food Sci. Technol. 2016, 73, 584-591. [CrossRef] 
114. Xu, K.; Guo, M.; Roman, L.; Pico, J.; Martinez, M.M. Okra seed and seedless pod: Comparative study of their phenolics and carbohydrate fractions and their impact on bread-making. Food Chem. 2020, 317, 126387. [CrossRef] [PubMed]

115. Sivam, A.S.; Sun-Waterhouse, D.; Perera, C.O.; Waterhouse, G.I.N. Exploring the interactions between blackcurrant polyphenols, pectin and wheat biopolymers in model breads; a FTIR and HPLC investigation. Food Chem. 2012, 131, 802-810. [CrossRef]

116. Ning, J.; Hou, G.G.; Sun, J.; Wan, X.; Dubat, A. Effect of green tea powder on the quality attributes and antioxidant activity of whole-wheat flour pan bread. LWT Food Sci. Technol. 2017, 79, 342-348. [CrossRef]

(C) 2020 by the authors. Licensee MDPI, Basel, Switzerland. This article is an open access article distributed under the terms and conditions of the Creative Commons Attribution (CC BY) license (http://creativecommons.org/licenses/by/4.0/). 